\title{
ANALISIS PERKAWINAN ANAK USIA DINI DITINJAU DARI UNDANG-UNDANG NOMOR 1 TAHUN 1974 DAN UNDANG-UNDANG NOMOR 35 TAHUN 2014
}

\author{
Surianto* \\ PT. Pusat Edukasi International
}

\begin{abstract}
Marriage is a very reasonable thing for human beings who want to build a household or family that is in accordance with their respective religious beliefs. In Indonesia, the law of marriage is recorded in Act Number 11974 concerning Marriage. Marriage can only be carried out if the age of the individuals in the marriage is sufficient in accordance with the rules of the marriage law. Insufficient age for the marriage is categorized as child marriage. In Act Number 232002 concerning Child Protection, children are individuals who do not exceed 18 years of age. The rise of child marriage in Indonesia has troubled the Indonesian government in eradicating or preventing child marriage. The implementation of child marriages has great impact on children who conduct it, such as the existence of Domestic Violence, the discontinuation of a child's education, health effects for girls, the impact of pregnancy or the womb and the influence of pysicology and biology of children. In the case of thesis research, the type of research used is normative research and the data used is based on Laws, Journals, Articles, and Books to obtain data. The method of data analysis in this study is Qualitative in which the explanation is set descriptively. Prevention of child marriage must be maximally carried out by law enforcement which in accordance with applicable laws. Maximal prevention can reduce the number of child marriages, in addition to carrying out socialization regarding the dangers of child marriage.
\end{abstract}

Keywords: Early child marriage, prevention, child marriage risk.

\begin{abstract}
Abstrak
Perkawinan dapat dikatakan sebagai hal yang sangat wajar dilakukan oleh umat manusia yang ingin membangun rumah tangga atau keluarga yang bersesuaian dengan kepercayaan agama masing-masing, dalam perkawinan Indonesia aturan hukum perkawinan tercatat dalam Undang-Undang Nomor 1 Tahun 1974 tentang Perkawinan. Perkawinan hanya dapat dilaksanakan jika usia perkawinan mencukupi sesuai dengan aturan hukum perkawinan, usia yang belum mencukupi usia perkawinan masih termasuk kategori sebagai anak. Dalam Undang-Undang Nomor 23 Tahun 2002 tentang Perlindungan Anak, Anak ialah yang tidak melebihi usia 18 tahun. Maraknya perkawinan usia dini di Indonesia meresahkan pemerintahan Negara Indonesia dalam memberantas atau mencegah perkawinan usia dini. pelaksanaan perkawinan usia dini sangat berdampak besar bagi anak yang melakukannya, seperti adanya Kekerasan Dalam Rumah Tangga (KDRT), putusnya pendidikan anak, dampak kesehatan bagi anak wanita, dampak kehamilan
\end{abstract}

*Alamat Korespondensi : frengkysun@gmail.com 
atau kandungan dan pengaruh pysikologi dan biologi anak. Dalam hal penelitian jenis penelitian yang digunakan ialah penelitian normatif, dan data yang digunakan berdasarkan Undang-Undang, Jurnal, Artikel, dan Buku-Buku untuk memperoleh kedataan, serta metode analisa data dalam penelitian ini bersifat Kualitatif yang penjelasannya disusun secara deskriptif. Pencegahan perkawinan usia dini harus dilaksanakan atau dilakukan oleh penegakan hukum yang secara maksimal sesuai dengan Undang-Undang yang berlaku. Pencegahan yang secara maksimal dapat menurunkan angka perkawinan usia dini, bukan hanya secara maksimal akan tetapi harus dilaksanakan juga sosialisasi mengenai bahayanya perkawinan usia dini.

Kata Kunci : Perkawinan anak usia dini, pencegahan, resiko perkawinan anak

\section{A. Latar Belakang Masalah}

Anak merupakan aset berharga yang dapat meneruskan cita-cita suatu bangsa dan negara, dengan menjaga serta melindungi anak merupakan tugas suatu negara untuk memenuhi konstitusi. melindungi anak dapat dilakukan dengan cara memberikan pendidikan, menjaga anak untuk tumbuh berkembang, dan tidak ada diskriminasi sesama anak di suatu negara, untuk dari itu negara harus melindungi hak-hak anak yang dapat membuat anak menjadi buruk, perkawinan usia dini, dan mengalami kekerasan fisik maupun mental seorang anak ${ }^{1}$.

perkawinan usia anak atau usia dini sangat berdampak buruk dan negatif bagi anak-anak Indonesia, dalam hal berdampak buruk dan negatif bagi anakanak sangat banyak sekali seperti, dampak buruk atau negatif pada kesehatan anak, dampak buruk terhadap hak-hak pendidikan anak, dampak buruk terhadap psikologis terhadap fisik maupun mental terhadap anak, berdampk pada angka kematian ibu dan anak, dan berdampak buruk juga terjadi Kekerasan Dalam Rumah Tangga (KDRT).

Berdasarkan Badan Pusat Statistik (BPS) Tahun 2018 perkawinan yang dilaksanakan oleh seorang anak berpengaruh terhadap pendidikan sebesar 0,40\% tidak pernah sekolah, tidak Tamat SD sebesar 38,07\%, SD sebesar $35,57 \%$, SMP sebesar 25,53\% dan SMA ke atas sebesar $0,43 \%{ }^{2}$, berdasarkan data persentase yang telah disajikan perkawinan yang dilaksanakan oleh seorang anak berdampak pada tamatnya atau selesainya pendidikan yang seharusnya diterima oleh seorang anak. Dalam konstitusi negara Indonesia yaitu Undang-Undang Dasar Republik Indonesia Tahun 1945 pada Pasal 28B

\footnotetext{
${ }^{1}$ Putri Dwi Melati, "Implementasi Penanganan Kasus Kekerasan Terhadap Anak Oleh Komisi Perlindungan Anak Indonesia”, Journal Fiat Justisia Ilmu Hukum, Volume 9, Nomor 1, JanuariMaret 2015, Hlm 34

2 Badan Pusat Statistik (BPS), "Profil Anak Indonesia 2018", https://www.kemenpppa.go.id/lib/uploads/list/74d38-buku-pai-2018.pdf, diakses 02 September 2019, Hlm. 44
} 
ayat (2) menyatakan bahwa setiap anak berhak berkelangsungan hidup, tumbuh berkembang, dan mendapatkan perlindungan dari diskriminasi, yang artinya seluruh anak Indonesia harus memperoleh perlindungan dari orang tua, masyarakat, dan pemerintah yang mewakili negara dan memenuhi hakhak yang telah diatur dalam konstitusi negara.

Perkawinan usia dini oleh seorang anak merupakan salah satu bentuk diskriminasi atau perlakuan buruk yang melanggar hak-hak anak yang diatur dalam Pasal 28B ayat (2) Undang-Undang Dasar Republik Indonesia Tahun 1945 yang dimana hak-hak anak tumbuh berkebang menjadi terhambat akibat dari perkawinan usia dini.

Perkawinan sendiri diatur dalam Undang-Undang Nomor 1 Tahun 1974 tentang Perkawinan, yang dimana untuk melaksanakan perkawinan harus memenuhi beberapa syarat-syarat yang diatur dalam Undang-Undang Perkawinan. Dalam Pasal 6 Undang-Undang Nomor 1 Tahun 1974 menjelaskan bahwa untuk melaksanakan perkawinan mempelai atau pihakpihak yang bersangkutan harus mencapai usia 21 tahun dan mendapatkan izin dari orang tua harus dibawah 21 tahun $^{3}$. Artinya jika seseorang yang belum mencapai 21 tahun atau dibawah 21 tahun harus memperoleh izin dari orang tua untuk melaksanakan perkawinan.

Kemudian dalam Pasal 7 Undang-Undang Nomor 1 Tahun 1974 tentang Perkawinan mengatur mengenai syarat-syarat perkawinan yang dimana seorang laki-laki harus mencapai usia 18 tahun dan seorang wanita harus mencapai usia 16 tahun ${ }^{4}$. Artinya dalam Pasal 7 memberikan pilihan kepada mempelai atau pihak yang bersangkutan untuk melaksanakan perkawinan atau tidak melaksanakan perkawinan, karna dalam Pasal 6 juga jelas jika belum mencapai usia 21 tahun harus mendapatkan izin orang tua, dan Pasal 7 tidak mewajibkan pada usia laki-laki 18 tahun dan wanita 16 tahun melaksanakan perkawinan.

Berdasarkan Pasal 6 dan Pasal 7 Undang-Undang Perkawinan memberikan kewenangan kepada orang tua untuk memberikan izin perkawinan jika usia anak dibawah 21 tahun, dan dalam Undang-Undang 23 Tahun 2002 tentang Perlindungan Anak Pasal 1 menjelaskan mengenai anak adalah seseorang yang belum mencapai usia 18 tahun. Yang artinya jika seseorang tidak berusia 18 tahun dianggap sebagai seorang anak, kemudian dalam Pasal 26 Undang-Undang Perlindungan Anak mengenai kewajiban orang tua terhadap anak yaitu mendidik, tumbuh kembangkan, mengeluarkan

${ }^{3}$ Undang-Undang Nomor 1 Tahun 1974 tentang Perkawinan (Lembaran Negara Republik Indonesia Tahun 1974 Nomor 1)

4 ibid 
bakat seorang anak dan mencegah perkawinan usia dini. dalam Pasal 26 jelas menjelaskan bahwa orang tua harus mencegah perkawinan usia dini.

Perkawinan usia dini terhadap anak banyak sekali resiko-resiko pelanggaran hak-hak anak dan berdampak pada pendidikan dan kesehatan utamanya yang membuat anak tidak bisa tumbuh berkembang sesuai dengan konstitusi negara.

\section{B. Rumusan Masalah}

Berdasarkan pada latar belakang diatas, maka rumusan masalah yang penulis rumuskan sebagai berikut :

1. Bagaimanakah Perlindungan Hukum Indonesia untuk kasus anak yang menikah diusia dini?

2. Apakah solusi yang tepat dalam mencegah terjadinya kasus anak menikah diusia dini?

\section{Metode Penelitian}

Metode penelitian yang digunakan penulis dalam penelitian ini adalah penelitian normatif, penelitian normatif merupakan penelitian yang didasarkan dengan membaca, mengkaji dan memahami aturan hukum positif yang berlaku, Undang-Undang Dasar Tahun 1945, kaidah-kaidah hukum, norma hukum, dan pendapat-pendapat hukum atau Doktrin lainnya ${ }^{5}$, yang didukung oleh data skunder seperti jurnal, kepustakaan, dan teori atau konsep hukum lainnya. Penelitian normatif dapat dikatakan sebagai penelitian ilmiah yang dilakukan dengan menelaah buku-buku hukum, jurnal hukum, artikel hukum dan doktrin-doktrin hukum yang digunakan untuk membantu melengkapi pemahaman-pemahaman mengenai hukum-hukum yang ada dan memberikan solusi penyelsaian penelitian. Selain penelitian normatif, data dalam penelitian yang digunakan penulis dalam hal ini adalah data skunder yang terdiri dari 2 bahan hukum yaitu bahan hukum primer dan bahan hukum skunder, bahan hukum primer yang digunakan adalah Undang-Undang Dasar Tahun 1945, dan Undang-Undang kemudian bahan hukum skunder yang digunakan adalah studi pustaka dan jurnal-jurnal atau artikel-artikel hukum. Dan metode analisis data dalam penelitian ini adalah metode kualitatif, yang dimana kualitatif adalah metode analisis yang menjelaskan dan menyelsaikan dengan cara deskriptif.

\section{Hasil Penelitian dan Pembahasan}

${ }^{5}$ Noor Inna Inayati, "Perkawinan Anak Di Bawah Umur dalam Prespektif Hukum, HAM dan Kesehatan", Jurnal Bidan "Midwife Journal”, Volume 1, Nomor 1, Januari 2015, Halaman 48 


\section{Perlindungan Hukum bagi perkawinan anak usia dini}

Perkawinan adalah hubungan antara lelaki dengan perempuan yang menginginkan status pasangan suami istri yang membentuk keluarga bahagia, menebarkan kasih sayang dan bertakwa kepada kepercayaan agamanya masing-masing ${ }^{6}$. Dalam Undang-Undang Perkawinan Nomor 1 Tahun 1974 perkawinan hanya dapat diksanakan sesuai dengan Pasal 6 dan Pasal 7 yang dimana dalam Pasal 6 untuk melaksanakan perkawinan harus berusia 21 tahun dan dibawah 21 tahun harus memperoleh izin dari orang tua untuk melaksanakan perkawinan. Kemudian dalam Pasal 7 mengenai syarat-syarat perkawinan yaitu lakilaki berusia 18 tahun dan wanita 16 tahun.

Dalam Undang-Undang Nomor 23 Tahun 2002 tentang Perlindungan Anak menjelaskan bahwa kewajiban orang tua tercantum dalam pasal 26 yang berbunyi ${ }^{7}$ : "orang tua berkewajiban sebagai berikut :

1. Mengasuh,mendidik, dan melindungi anak

2. Melahirkan bakat,kemampuan, dan minat anak

3. Mencegah perkawinan usia dini"

Berdasarkan bunyi Pasal diatas jelas bahwa seorang orang tua harus mendidik anak menjadi orang yang berpribadi atau berkarakter yang dapat menentukan sendiri jalan yang diinginkan. Selain mendidik atau melahirkan bakat seorang anak, orang tua juga harus mencegah perkawinan usia dini yang jelas tercantum dalam Pasal 26 UndangUndang Perlindungan Anak.

Jika dilihat dari kedua Undang-Undang mengenai Perkawinan dan Perlindungan Anak, seharusnya sebagai seorang orang tua paham mengenai perkawinan yang diatur dalam Undang-Undang Nomor 1 Tahun 1974. Perkawinan yang diatur dalam Undang-Undang Perkawinan diperuntukkan bagi orang yang telah dewasa dan mampu membentuk keluarga yang damai,bahagia dan berdasarkan kepercayaan agama masing-masing. Perkawinan yang dilaksanakan oleh seorang anak dibawah umur atau usia sangat tidak tepat dilakukan oleh seorang orang tua karna telah bertentangan dengan konstitusi negara Indonesia dan

${ }^{6}$ Rahman Faiz dan Nur Rizka Faiza, "Perkawinan Siri Online Ditinjau Dari Prespektif Hukum Perkawinan Islam yang berlaku di Indonesia", Journal Penelitian Hukum, Volume 1, Nomor 1, Maret 2014, Halaman 37

${ }^{7}$ Undang-Undang Nomor 23 Tahun 2002 tentang Perlindungan Anak (Lembaran Negara Republik Indonesia Tahun 2002 Nomor 109) 
bertentangan dengan Undang-Undang Perlindungan Anak yaitu mengenai hak-hak seorang anak dan kewajiban sebagai orang tua.

Selain itu dalam Undang-Undang Perlindungan Anak juga mengatur mengenai hak-hak anak yang dalam kawasan perlindungan orang tua yang tercantum dalam Pasal 13 yang berbunyi :

"Setiap anak selama dalam pengasuhan orang tua, wali, atau pihak lain berhak mendapat perlindungan dari perlakuan:

1. diskriminasi;

2. eksploitasi;

3. penelantaran;

4. kekerasan,dan penganiayaan;

5. ketidakadilan;

6. perlakuan buruk"

jadi jika diperhatikan pada Pasal 13, perkawinan anak usia dini merupakan pelanggaran yang salah satunya dilakukan oleh seorang orang tua yaitu perlakuan buruk terhadap anaknya. Padahal dalam suatu perkawinan yang dilaksanakan akan menimbulkan hak-hak dan kewajiban-kewajiban yang harus dipikul atau dibebani oleh seorang anak. dan seorang anak tidak boleh membebani atau memikul hak dan kewajiban yang berat bagi seorang anak.

Menurut mentri kesehatan perkawinan usia dini yang dilaksanakan tidak memenuhi syarat-syarat perkawinan seperti usia yang diatur dalam Undang-Undang Perkawinan memiliki beberapa resiko-resiko atau dampak buruk bagi seorang anak terutama pada seorang wanita. Beberapa resiko-resiko atau dampak buruk yang akan terjadi jika seorang anak melakukan perkawinan usia dini ${ }^{8}$, sebagai berikut :

1. berdampak pada pendidikan

pendidikan merupakan ilmu pengetahuan yang disediakan oleh negara atau pemerintah untuk mewujudkan konstitusi negara, yang dimana pendidikan diberikan kepada anak-anak untuk tumbuh berkembang dan mewujudkan cita-cita anak.

Pendidikan sendiri merupakan hak-hak anak untuk belajar dan mengetahui atau memahami ilmu pengetahuan untuk melahirkan bakat-bakat anak yang tersembunyi di dalam diri seorang anak. Dalam sistem pendidikan Indonesia terdiri dari 3 tingkatan pendidikan yaitu SD, SMP, dan SMA/SMK. Dalam 3 tingkatan

${ }^{8}$ Zulfiani, "Kajian Hukum Terhadap Perkawinan Anak di Bawah Umur Menurut Undang-Undang Nomor 1 Tahun 1974", Jurnal Hukum Samudra Keadilan, Volume 12, Nomor 2, Juli-September 2017, Halaman 219 
tersebut memberikan banyak ilmu pengetahuan yang dapat membuat anak memilih bakat-bakat yang tersembunyi pada dirinya dan dikembangkan demi masa depan anak dan negara.

Perkawinan usia dini akan berdampak pada pendidikan salah satunya yang terjadi di Indonesia adalah putusnya atau tamatnya pendidikan akibat dari perkawinan. Perkawinan usia dini memberikan penyempitan terhadap hak-hak anak atau hilangnya hak-hak anak yang diatur dalam Undang-Undang Perlindungan Anak dan konstitusi negara sehingga anak yang melakukan perkawinan usia dini memutuskan berhenti melanjutkan pendidikan. Dalam perkawinan itu sendiri memiliki hak-hak dan kewajibankewajiban yang berbeda dengan hak-hak seorang anak yang dimana hak dari seorang anak adalah memperoleh pendidikan untuk perkembangan anak tersebut, dan hak dari perkawinan memberikan pertanggungjawaban antara suami dan istri yang sangat berat untuk dibebani oleh seorang anak sehingga perkawinan usia dini mengakibatkan putusnya pendidikan anak.

2. Berdampak pada psikologis

Secara tanpa disadari perkawinan usia dini akan berdampak pada psikologis seorang anak yang dimana anak yang masih memiliki pola pikiran yang sempit harus membebani hak dan kewajiban yang berat seperti orang tua dalam perkawinan. Dengan membebani hak dan kewajiban yang berat akan mengakibatkan membuat seorang anak menjadi gila atau stress membebani hal tersebut.

Perkawinan bukan hanya sebuah prosesi atau pesta perkawinan saja, akan tetapi membutuhkan pemikiran-pemikiran yang luas atau lebih dewasa untuk terhindar dari gangguan psikologi. Untuk menghindari gangguan psikologi anak harus memperoleh pendidikan yang layak dan tumbuh menjadi dewasa dengan pola pemikiran yang luas ${ }^{9}$. Bukan hanya secara pikiran akan tetapi butuh fisik dan mental yang kuat juga agar psikologi anak tidak terganggu.

3. Berdampak pada biologis

Tanpa disadari perkawinan usia dini selain berpengaruh pada psikologi seorang anak, dapat berpengaruh juga terhadap biologis seorang anak karna dalam rentang usia 6 tahun sampai dengan 18 tahun merupakan masa suburnya atau perkembangan atau pertumbuhan kedewasaaan seorang anak. Dalam perkawinan usia

${ }^{9}$ Ibid, hlm 219 
dini juga dapat menghambat pertumbuhan dan perkembangan secara biologis terhadap anak dan akan berakibatkan gagalnya atau lambatnya perkembangan atau pertumbuhan terhadap anak. Salah satunya seperti perkembangan atau pertumbuhan pada reproduksi wanita, pada masa rentang usia 6 tahun sampai 18 tahun reproduksi wanita sedang mengalami perkembangan yang matang untuk beradaptasi dalam diri. Bukan hanya reproduksi terhadap wanita saja untuk laki-laki dalam rentang usia yang sama dengan wanita juga mengalami masa subur untuk membuahi seorang anak di masa yang akan datang pada perkawinan yang mencukupi usia dan membangun rumah tangga yang harmonis.

4. Berdampak pada kesehatan

Berdasarkan riset kementrian kesehatan perkawinan usia dini yang dilaksanakan oleh seorang anak sangat berdampak buruk bagi anak, baik dari sudut kesehatan maupun non-kesehatan. Resiko yang terjadi pada kesehatan jika dilaksanakan perkawinan usia dini adalah salah satunya kanker serviks serta penyakit menular seksual ${ }^{10}$. Selain resiko kanker serviks dan penyakit menular seksual, perkawinan usia dini juga mengakibatkan komplikasi kehamilan dan persalinan yang dimana persalinan akan menjadi macet atau sulit mengeluarkan kepala anak yang berada dalam kandungan karna besar kepala anak tidak dapat disesuaikan dengan bentuk punggung yang sempurna oleh seorang anak ${ }^{11}$.

Berikut resiko atau dampak buruk kesehatan bagi seorang wanita yang menikah dibawah usia dini ${ }^{12}$ :

1. Dalam ilmu kedokteran, alat reproduksi seorang wanita yang dibawah 20 tahun belum siap untuk melakukan hubungan badan dengan lawan pasangannya karna dalam rentang usia tersebut mengalami perkembangan atau pertumbuhan sel reproduksi. Jika dipaksakan maka akan terjadi tekanan darah tinggi dan pendarahan oleh wanita.

2. Kondisi sel telur pada wanita, pada wanita dibawah usia 20 tahun kondisi sel telur belum matang atau belum sempurna sehingga kemungkinan akan terjadi kecacatan terhadap anak.

\footnotetext{
${ }^{10}$ Hanum Yuspa, Tukiman, "Dampak Pernikahan Dini Terhadap Kesehatan Alat Reproduksi Wanita", Jurnal Keluarga Sehat Sejahterah, Volume 13 (26), Desember 2015, Hlm 36

${ }^{11}$ Ibid, hlm 36

${ }^{12}$ Ibid, hlm 40
} 
3. Kanker serviks yaitu penyakit kanker leher rahim yang dimana diserang oleh virus-virus di daerah reproduksi wanita akibat berhubungan dibawah usia dini atau belum adanya kematangan pada reproduksi wanita.

Berdasarkan resiko-resiko atau dampak buruk diatas sangat berbahaya bagi seorang anak terutama bagi seorang anak wanita, karna akan berakibatkan pada kesehatan dan kematian pada seorang anak yang dilahirkan.

Berdasarkan resiko-resiko atau dampak buruk yang akan terjadi pada anak, pemerintah berupaya untuk bertindak mengeluarkan aturanaturan hukum untuk mencegah perkawinan usia dini karna dampak yang berbahaya dan hak-hak seorang anak yang dirampas akibat perkawinan. Dengan adanya tindakan pemerintah baik melalui aturan-aturan hukum atau penegakan hukum yang berlaku merupakan salah satu perlindungan hukum terhadap anak maupun setiap manusia. Dalam perlindungan hukum menurut Philipus M.Hadjon perlindungan Hukum terbagi 2 jenis yaitu :

1. Perlindungan Hukum Preventif

2. Perlindungan Hukum Represif

Perlindungan hukum preventif merupakan perlindungan hukum yang bersifat untuk mencegah suatu permasalahan yang dihadapi oleh setiap orang sebelum adanya sengketa atau permasalahan. Artinya perlindungan hukum preventif memberikan pencegahan terhadap setiap manusia agar tidak melanggar ketentuan-ketentuan baik dari aturan hukum positif maupun aturan tidak tertulis yang berlaku. Sedangkan perlindungan hukum represif merupakan perlindungan hukum yang bersifat menyelsaikan suatu permasalahan atau sengketa dengan hukuman atau sanksi yang dijatuhkan sesuai dengan aturan hukum positif $^{13}$.

Seperti pada kasus perkawinan usia dini oleh seorang anak Kabupaten Bantaeng, Sulawesi Selatan. Perkawinan usia dini yang dilaksanakan anak tersebut merupakan kesalahan keputusan yang diambil oleh anak, padahal anak tersebut masih duduk dibangku SMP yang perkawinannya berusia 13 tahun dan 14 tahun. Sesuai dengan ketentuan Undang-Undang Perkawinan Pasal 7 mengenai batas syarat perkawinan usia dini jelas menyebutkan bahwa usia laki-laki 18 tahun dan wanita 16 tahun untuk perkawinan, dan Pasal 6 juga menyatakan

${ }^{13}$ Febryka Luthvi Nola, "Upaya Perlindungan Hukum Secara Terpadu Bagi Tenaga Kerja Indonesia (TKI)”, Jurnal Negara Hukum, Volume 7, Nomor 1, Juni 2016, Hlm 40 
bahwa untuk meaksanakan perkawinan harus 21 tahun dan dibawah 21 tahun harus memperoleh izin orang tua. Berdasarkan Pasal 6 dan Pasal 7 Undang-Undang Perkawinan seharusnya perkawinan usia dini tidak terjadi dan dapat cegah karna usia anak tidak mencukupi.

Dan keputusan yang diambil anak tersebut telah menempuh jalur permohonan dispensasi di pengadilan dengan alasan takut tidur sendirian dan salah satu orang tua telah meninggal dan anak tersebut hidup dirumah sendirian sementara ayahnya berkerja diluar kelurahan untuk menafkahi anak dan dirinya. Seharusnya sesuai dengan Pasal 26 UndangUndang Perlindungan Anak mengenai kewajiban orang tua harus tumbuh kembangkan bakat anak dan mencegah perkawinan usia dini. tetapi yang terjadi dilapangan perkawinan anak tersebut terlaksana dan sah dimata hukum. Berarti orang tua pada kasus tersebut telah lalai dalam melaksanakan kewajibannya sebagai orang tua dalam mendidik anak, padahal anak tersebut tidak bisa melaksanakan perkawinan jika Pasal 6 dan Pasal 7 Undang-Undang Perkawinan tidak terpenuhi karna anak yang dibawah 18 tahun masih merupakan pertanggung jawaban orang tua, artinya orang tua masih memiliki hak untuk membatalkan perkawinan usia dini tersebut.

Jika dilihat melalui sudut pandang perlindungan hukum preventif, mengenai perkawinan usia dini pada kasus tersebut tidak ada upaya pencegahan atau perlindungan preventif baik dari orang tua maupun masyarakat, padahal dalam aturan Undang-Undang Perkawinan dan Undang-Undang Perlindungan Anak jelas mengatur mengenai perkawinan. Hanya aparat penegakan hukum seperti orang tua, masyarakat dan pemerintah kesadaran hukum mengenai aturan perkawinan sangat dangkal atau minim sehingga tidak memandang bahwa perkawinan usia dini oleh anak memiliki resiko-resiko dan hilangnya hak-hak anak yang telah diatur dalam konstitusi.

Seharusnya dengan adanya aturan Undang-Undang Perkawinan dan Undang-Undang Perlindungan Anak serta adanya penegakan hukum dapat mencegah terjadinya perkawinan usia dini atau merupakan teori perlindungan hukum preventif yang dibuat oleh negara untuk menjamin hak-hak anak yang tercantum dalam konstitusi, serta memberikan pertanggung jawaban atau tugas dari selaku orang tua dalam mendidik dan merawat anaknya. 


\section{Solusi Pencegahan Perkawinan Usia dini}

Jika dilihat dari resiko-resiko atau akibat buruk yang terjadi pada perkawinan usia dini terhadap anak, perlu adanya upaya penegahan perkawinan usia dini atau perlindungan hukum preventif yang dilakukan oleh pemerintah, orang tua dan masyarakat. Karna dalam perkawinan usia dini selain resiko yang timbul terhadap anak ada juga hak-hak anak yang telah diambil secara paksa.

Solusi pencegahan perkawinan usia dini merupakan upaya perlindungan hukum yang bersifat preventif dimana jika aturan UndangUndang yang dibuat negara tidak bisa mencegah atau memberikan perlindungan terhadap anak maka perlu adanya tindakan dari pemerintah baik dari pusat maupun daerah untuk memberikan pengetahuan mengenai perkawinan dan bahayanya perkawinan usia dini. dengan langkah pemberitahuan atau pengetahuan hukum kepada masyarakat dan orang tua dapat meningkatkan kesadaran hukum setiap manusia.

Kesadaran hukum sendiri merupakan teori yang terdapat dalam pikiran manusia yang membentuk kaidah-kaidah hukum mengenai hukum seperti benar atau salah, adil atau tidak adil dan baik atau buruk yang timbul dalam kesadaran manusia, atau kesadaran hukum dapat dikatakan sebagai kesadaran berprilaku seseorang seyogyanya dengan cara adanya keadilan ${ }^{14}$. Artinya kesadaran hukum ialah kesadaran yang ada pada setiap manusia mengenai perilaku yang diputuskan atau dilaksanakan seseorang yang telah diatur dalam Undang-Undang, hanya perilaku tersebut atau keputusan tersebut yang diambil oleh setiap manusia belum bisa dikatakan benar atau salah, adil atau tidak adil dan baik atau buruk jika dalam aturan tersebut tidak memuat tindakan yang dilakukan oleh seseorang.

Dalam pencegahan perkawinan usia dini perlu adanya beberapa langkah-langkah pencegahan baik oleh pemerintah maupun orang tua untuk melindungi hak-hak anak yang diatur dalam konstitusi, sebagai berikut :

1. Perlu adanya program-program dari lembaga pemerintahan baik itu sosialisasi oleh pemerintah ke masyarakat maupun program pelaksanaan mengenai resiko atau akibat dari perkawinan usia dini.

2. Perlu ditingkatkan kesadaran orang tua mengenai kewajibannya yang diatur dalam Undang-Undang Nomor 23 Tahun 2002 tentang Perlindungan Anak Pasal 26 untuk mencegah perkawinan usia dini

${ }^{14}$ Sibuea Harris Y.P,"Penegakan Hukum Pengaturan Minuman Beralkohol”, Jurnal Negara Hukum, Volume 7, Nomor 1, Juni 2016, Halaman 132 
dan mendidik anaknya hingga melahirkan sebuah bakat pada dalam diri anak.

3. Perlu adanya pegawasan di bidang pendidikan tepatnya di sekolahsekolah tempat anak menempuh pendidikan, karna anak tidak akan mengenal artinya perkawinan jika tidak didasari dengan adanya pacaran atau kedekatan yang tidak biasa dilakukan oleh seorang lakilaki dan wanita. Dan menurut survei yang ada jumlah remaja Indonesia tepatnya perempuan sekitar 33,3\% dan laki-laki $34,5 \%$ berpacaran dalam rentang usia 15 tahun sampai 17 tahun $^{15}$.

4. Selain pengawasan yang dilakukan melalui orang tua dan pemerintah, pengawasan terhadap anak juga harus dilaksanakan oleh masyarakat sekitar. Yang dimana peran masyarakat harus membantu pemerintah dalam menjalankan aturan hukum. Karna hukum yang dibuat oleh pemerintah atau negara bersifat mengikat publik dan hukum akan berjalan jika ada masyarakat yang taat dan melaksanakan atau menjalankan aturan hukum tersebut.

Dengan adanya upaya pemerintah dalam pencegahan usia dini sangat membantu bagi masyarakat dan orang tua tepatnya untuk mengingat kembali kesadaran hukum mengenai Perkawinan dan Perlindungan Anak.

Mengenai teori kesadaran hukum, menurut soerjono soekanto teori kesadaran hukum memiliki 4 faktor yang mempengaruhinya, sebagai berikut $^{16}$ :

1. Pengetahuan Hukum

2. Pemahaman Hukum

3. Sikap Hukum

4. Pola Perilaku Hukum

Berdasarkan 4 faktor diatas, kesadaran hukum akan lahir jika masyarakat dan pemerintah dalam menjalankan tugasnya memiliki jiwa kesadaran yang tinggi dan taat terhadap sebuah aturan hukum yang dibuat oleh negara dan dijalankan dengan sepenuh hati.

Untuk memahami mengenai 4 faktor yang telah dikemukakan oleh soerjono soekanto dalam teorinya mengenai kesadaran hukum, harus

\footnotetext{
15 Ohee Christine, Windhu Purnomo, "Pengaruh Status Hubungan Berpacaran Terhadap Perilaku Pacaran Berisiko pada Mahasiswa Perantau Asal Papua di Kota Surabaya”, The Indonesian Journal Public Health, Volume 13, Nomor 2, Desember 2018, Halaman 269

${ }^{16}$ Rosana Ellya, "Kepatuhan Hukum sebagai Wujud Kesadaran Hukum Masyarakat”, Jurnal TAPIs, Volume 10, Nomor 1, Januari-Juni 2014, Halaman 14
} 
dikaitkan dengan kasus-kasus yang ada seperti perkawinan usia dini yang dilakukan oleh berbagai anak.

pertama mengenai pengetahuan hukum, pencegahan perkawinan anak usia dini telah diatur dalam Undang-Undang Perlindungan Anak yang dituliskan dalam Pasal 26 yang menjadi tanggung jawab orang tua atau kewajiban orang tua dalam mendidik anaknya, kemudian dalam Undang-Undang Perkawinan mengenai syarat-syarat perkawinan secara logis aturan tersebut dibuat untuk melakukan pencegahan dengan dibatasi minimal usia perkawinan.

Dengan adanya aturan hukum tersebut orang tua, masyarakat maupun lembaga pemerintahan harus memiliki pengetahuan terhadap sebuah aturan tersebut. Jika dihubungkan dengan kasus perkawinan anak usia dini Kecamatan Bantimurung, Sulawesi Selatan, dan perkawinan anak usia dini Kabupaten Balangan Kalimantan Selatan, pengetahuan dari orang tua mengenai perkawinan sangat minim sehingga perkawinan yang dilaksanakan melanggar ketentuan Pasal 7 Undang-Undang Perkawinan, jika pengetahuan orang tua mengenai hukum perkawinan tinggi dan cukup maka perkawinan usia dini pada anaknya tidak akan terjadi atau terlaksana. Jika dilihat pada kasus perkawinan anak usia dini Kabupaten Bantaeng, Sulawesi Selatan, yang dimana salah satu orang tuanya meninggal dan orang tuanya berkerja ke luar wilayah serta tidak pernah pulang dan memiliki seorang anak berusia 13 tahun duduk di bangku SMP telah melakukan perkawinan dengan teman sebangku dengan mendapatkan dispensasi perkawinan, padahal dalam rentang usia tersebut dan duduk di bangku SMP, seharusnya dalam bangku SMP pengetahuan yang diterima atau diserap dapat di analisis atau di analisa dampak perkawinan usia dini, sehingga pencegahan perkawinan usia dini tidak dapat dilaksanakan oleh anak mereka karna mengetahui bahaya atau resiko-resiko yang diterima nantinya.

Kedua mengenai Pemahaman Hukum, dalam sebuah aturan hukum terdapat Pasal-Pasal yang mengatur secara rinci sebuah aturan, orang tua, masyarakat dan lembaga pemerintahan harus memahami Pasal-Pasal aturan hukum tersebut, jika tidak memahami aturan hukum tersebut maka aturan tersebut tidak akan berjalan sesuai dengan keinginan negara. Contohnya Undang-Undang Perkawinan Pasal 7 mengenai batas usia perkawinan, jika penegakan hukum tidak memahami isi tersebut maka usia berapa saja yang dianggap sudah siap dapat melakukan perkawinan, padahal usianya masih di bawah umur. Jika dihubungkan dengan kasus perkawinan anak usia dini, Kecamatan Bantimurung Sulawesi Selatan, 
perkawinan anak usia dini Kabupaten Bantaeng, Sulawesi Selatan dan perkawinan anak usia dini Kabupaten Balangan, Kalimantan Selatan, pemahaman hukum oleh masing-masing orang tua mengenai aturan perkawinan sangat minim, karna jelas dalam Pasal 7 aturan perkawinan mengenai usia perkawinan telah diatur batas usia, dan Pasal 26 perlindungan anak jelas menegaskan kewajiban orang tua dalam mengasuh anak salah satunya mencegah perkawinan usia dini. jika para orang tua memahami isi aturan tersebut atau makna isi aturan tersebut maka perkawinan usia dini dapat dicegah oleh orang tua dengan dibantunya lembaga pemerintahan dan masyarakat mengenai pemahaman hukum tentang perkawinan dan syarat-syarat perkawinan.

Jadi dengan adanya pemahaman hukum yang tinggi dan mudah dimengerti isi aturan tersebut maka, upaya pencegahan perkawinan usia dini dapat dicegah oleh orang tua.

Ketiga mengenai hal Sikap Hukum, dalam hal sikap hukum masyarakat memiliki peran sangat penting untuk menilai suatu hukum, apakah layak untuk dijalankan apa tidak dijalankan, sikap hukum merupakan perilaku masyarakat dalam menjalankan sebuah aturan hukum. Sikap hukum juga dapat menentukan sebuah aturan hukum dapat dijadikan hukum tertulis atau tidak, jika hukum dibuat dan disahkan tetapi masyarakat menolak maka hukum tersebut harus di perbaiki kembali melalui judicial review. Jika dikaitkan dengan perkawinan anak usia dini, Kecamatan Bantimurung Sulawesi Selatan, perkawinan anak usia dini Kabupaten Bantaeng, Sulawesi Selatan dan perkawinan anak usia dini Kabupaten Balangan, Kalimantan Selatan, sikap orang tua dalam perkawinan usia dini sangat tidak peduli terhadap aturan perkawinan, padahal dengan adanya aturan-aturan perkawinan tujuannya adalah untuk mengurangi atau mencegah perkawinan usia dini, aturan hukum dibuat untuk dilaksanakan atau ditaati oleh penegakan hukum bukan untuk dilanggar. Sikap masyarakat terhadap hukum perkawinan sangat tinggi untuk mencegah terjadinya perkawinan usia dini, hanya saja tidak semua masyarakat menanggapi aturan hukum perkawinan karna mementingkan keegoisan diri sendiri tanpa memikirkan hak-hak anaknya.

Mengenai sikap hukum, hukum yang dibuat harus tegas dan bersifat bermanfaat bagi masyarakat, jika dipandang dengan kasus perkawinan anak usia dini, Kecamatan Bantimurung Sulawesi Selatan, perkawinan anak usia dini Kabupaten Bantaeng, Sulawesi Selatan dan perkawinan anak usia dini Kabupaten Balangan, Kalimantan Selatan, aturan tentang 
perkawinan sangat bermanfaat bagi masyarakat untuk mencegah perkawinan usia dini, hanya dalam penegakan hukum tentang perkawinan tidak dijalankan oleh orang tua maupun masyarakat secara maksimal.

Mengenai sikap hukum pada kasus perkawinan anak usia dini, Kecamatan Bantimurung Sulawesi Selatan, yang dimana perkawinan tersebut dibantu oleh orang tua dan pihak KUA, telah melanggar aturan perlindungan anak dan aturan administrasi kependudukan karna jelas dalam aturan pasal-pasal tersebut, seperti Pasal 26 perlindungan anak menyatakan kewajiban orang tua salah satunya mencegah perkawinan usia dini, seharusnya orang tua harus menanggapi sikap hukum aturan tersebut, karna demi kepentingan anak untuk tumbuh dan berkembang sesuai dengan konstitusi negara, bukan membantu melaksanakan perkawinan usia dini. kemudian pihak KUA telah melanggar ketentuan Pasal 77 mengenai perubahan data kependudukan seseorang, padahal jelas dalam pasal tersebut seseorang tidak diizinkan merubah data seseorang tanpa hak, berdasarkan hal tersebut sikap hukum yang dilakukan oleh lembaga KUA telah melanggar pasal tersebut dan tidak menunjukkan kewibawaan seorang petugas KUA.

Selain kasus diatas terdapat juga kasus perkawinan anak usia dini Kabupaten Bantaeng, Sulawesi Selatan, yang kronologi kasus tersebut adalah anak yang melaksanakan perkawinan dengan alasan takut tidur sendirian dan mengajukan dispensasi perkawinan. Padahal jika dilihat mengenai sikap hukum, kedua anak tersebut tidak memahami atau kurangnya pengetahuan mengenai batas usia perkawinan, seharusnya pihak orang tua maupun lembaga KUA atau pengadilan Agama memperlihatkan sikap hukum mereka kepada kedua anak tersebut, bahwa perkawinan usia dini yang dilakukan telah melanggar ketentuan aturan yang berlaku dan akan mengalami beberapa resiko atau bahaya bagi kedua anak tersebut.

Dengan adanya keperihatian orang tua, KUA atau pengadilan Agama terhadap anak tersebut, menunjukkan sikap hukum yang baik dan benar dalam mencegah perkawinan usia dini, karna minimnya kepengetahuan anak-anak mengenai perkawinan, tidak memikirkan bahaya atau resiko yang diterima oleh anak.

Keempat Pola Perilaku Hukum, sebuah aturan hukum memiliki pola masa berlaku hukum dan pola pelaksanaan atau penerapan hukum, semakin lama usia sebuah hukum semakin efektif hukum tersebut di masyarakat. Tetapi sebaliknya jika usia hukum tersebut tidak panjang 
maka perlu adanya pembahruan hukum, baik melalui perubahanperubahan aturan hukum maupun merancang sebuah hukum baru, dan pola Penerapan atau pelaksanaan hukum juga menentukan kualitas atau kefektifitasan sebuah hukum, pola hukum yang memiliki masa waktu lama tetapi penerapan atau pelaksanaan hukumnya tidak sesuai maka hukum tersebut tidak akan berjalan dan sebaliknya juga pola masa waktu hukum pendek tetapi pola pelaksanaannya atau penerapannya maksimal, maka hukum dapat berjalan sesuai keinginan negara.

Jika dihubungkan dengan kasus perkawinan usia dini, Kecamatan Bantimurung, Sulawesi Selatan, perkawinan usia dini Kabupaten Bantaeng, Sulawesi Selatan, dan perkawinan usia dini Kecamatan Halong, Kalimantan selatan, seharusnya hukum perkawinan dan hukum perlindungan anak sangat efektif diterapkan, karna usia aturan hukum tersebut sangat lama berdiri di Indonesia, dan pola penerapan atau penegakannya sebagian masyarakat setuju dan menerima isi aturan hukum tersebut, dan dipandang sangat efektif untuk menyelsaikan permasalah anak dan permasalahan perkawinan yang dilaksanakan.

Selain kesadaran hukum orang tua dan masyarakat, pemerintah selaku mewakili negara harus memiliki jiwa kesadaran hukum yang lebih tinggi dari orang tua dan masyarakat dalam mencegah perkawinan usia dini. dalam pencegahan perkawinan usia dini terbagi beberapa cara, sebagai berikut ${ }^{17}$ :

1. Pendekatan pribadi, dalam hal ini pemerintah maupun orang tua harus menerangkan atau menjelaskan kepada anak yang melaksanakan perkawinan mengenai bahaya atau resiko perkawinan usia dini.

2. Pendataan, pemerintah sesuai dengan Undang-Undang Administrasi Kependudukan wajib melakukan pendataan atau pencatatan persitiwa penting guna menjalankan aturan hukum dan riset pendataan statistik tahunan apakah meningkat atau menurun.

3. Sosialisasi, pemerintah wajib melakukan sosialisasi terhadap masyarakat, orang tua, anak, dan sekolah-sekolah mengenai resiko perkawinan dan aturan hukum perkawinan, tidak semua masyarakat mengetahui perkawinan memiliki aturan hukum walaupun usia hukum perkawinan Indonesia sudah lama. Dengan adanya

${ }^{17}$ Latifatul Ana Muntamah, Dian Latifiani, Ridwan Arifin, "Pernikahan Dini Di Indonesia: Faktor dan Peran Pemerintah (Prespektif Penegakan dan Perlindungan Hukum Bagi Anak", Jurnal Widya Yuridika Jurnal Hukum, Volume 2, Nomor 1, Juni 2019, Halaman 8-9 
sosialisasi merupakan langkah awal pencegahan perkawinan usia dini.

4. Memperketat penerbitan akta perkawinan, dalam penerbitan akta perkawinan, biasanya perkawinan anak usia dini pengurusan administrasi dibantu oleh orang tua atau lembaga KUA.

5. Menjalankan hukum perkawinan secara profesional, pemerintah KUA dalam melangsungkan perkawinan harus secara tegas dan profesional menjalankan hukum perkawinan, misalnya jika usia perkawinan tidak mencukupi maka tidak dapat dilaksanakan perkawinan sampai mencukupi usia perkawinan.

Jadi dengan adanya beberapa langkah dan upaya-upaya pemerintah dalam mencegah perkawinan usia dini, jika diterapkan atau dijalankan sesuai dengan aturan hukum perkawinan dan perlindungan anak maka perkawinan usia dini dapat dicegah oleh orang tua dan masyarakat.

\section{E. Kesimpulan}

Berdasarkan hasil penelitian dan pembahasan yang diuraikan diatas mengenai perkawinan usia dini terhadap anak, terbagi menjadi 2 yaitu :

1. Mengenai perlindungan hukum, sesuai dengan Undang-Undang Nomor 23 Tahun 2002 tentang Perlindungan Anak dalam Pasal 26 perlu dilaksanakan atau dijalankan oleh seorang orang tua sebagaimana mestinya dan pengetahuan hukum atau kesadaran hukum perkawinan yang diatur dalam Undang-Undang Nomor 1 Tahun 1974 tentang perkawinan Pasal 7 yang merupakan syarat-syarat perkawinan dan Pasal 6 mengenai untuk melaksanakan perkawinan oleh setiap manusia. Dengan adanya perlindungan hukum preventif yang diterapkan oleh pemerintah atau instansi pelaksana dapat mencegah terjadinya perkawinan anak usia dini karna perkawinan bukan tempatnya anak tumbuh berkembang tetapi pendidikan. serta untuk melindungi dan menurunkan angka perkawinan usia dini perlu adanya pencegahan dan pengawasan terhadap perkawinan usia dini secara maksimal oleh orang tua, masyarakat dan pemerintahan.

2. Dalam hal melihat berbagai resiko atau akibat-akibat yang terjadi pada anak nantinya akibat dari perkawinan usia dini, solusi pencegahan yang tepat adalah :

1. Kesadaran dari orang tua, pemerintah dan masyarakat mengenai resiko atau bahayanya perkawinan anak usia dini dan pengetahuan hukum Undang-Undang Perkawinan serta Undang-Undang Perlindungan Anak. 
2. Menjalankan kewajiban orang tua sesuai dengan Pasal 26 UndangUndang Perlindungan Anak untuk mencegah perkawinan anak dan mencegah tradisi perkawinan anak usia dini di berbagai provinsi karna akan berakibat buruk bagi wanita dan anak nantinya serta dapat meningkatkan perkawinan anak usia dini jika tradisi pada perkawinan anak usia dini tidak dicegah atau ditata ulang kembali.

3. Dalam melakukan pencegahan perkawinan anak usia dini pemerintah harus konsisten atau profesional dalam menjalankan UndangUndang Perkawinan

4. Menerapkan Pasal 30 Undang-Undang Perlindungan Anak mengenai hak asuh yang dimana jika orang tua tidak bisa melaksanakan atau menjalankan kewajibannya sebagai orang tua harus digantikan kedudukannya dengan kedudukan wali sebagai pengawas yang mendidik dan membesarkan anak. Pergantian wali tersebut tidak akan menghilangkan kedudukan orang tua selama orang tua dapat bertanggung jawab menjalankan kewajibannya yang diatur dalam Pasal 26 Perlindungan Anak. 


\section{DAFTAR PUSTAKA}

\section{Artikel:}

Febryka Luthvi Nola, "Upaya Perlindungan Hukum Secara Terpadu Bagi Tenaga Kerja Indonesia (TKI)”, Jurnal Negara Hukum, Volume 7, Nomor 1, Juni 2016.

Hanum Yuspa, Tukiman, "Dampak Pernikahan Dini Terhadap Kesehatan Alat Reproduksi Wanita”, Jurnal Keluarga Sehat Sejahterah, Volume 13 (26), Desember 2015.

Latifatul Ana Muntamah, Dian Latifiani, Ridwan Arifin, "Pernikahan Dini Di Indonesia: Faktor dan Peran Pemerintah (Prespektif Penegakan dan Perlindungan Hukum Bagi Anak", Jurnal Widya Yuridika Jurnal Hukum, Volume 2, Nomor 1, Juni 2019.

Noor Inna Inayati, "Perkawinan Anak Di Bawah Umur dalam Prespektif Hukum, HAM dan Kesehatan”, Jurnal Bidan “Midwife Journal”, Volume 1, Nomor 1, Januari 2015.

Ohee Christine, Windhu Purnomo, "Pengaruh Status Hubungan Berpacaran

Terhadap Perilaku Pacaran Berisiko pada Mahasiswa Perantau Asal Papua di Kota Surabaya”, The Indonesian Journal Public Health, Volume 13, Nomor 2, Desember 2018.

Putri Dwi Melati, “Implementasi Penanganan Kasus Kekerasan Terhadap Anak Oleh Komisi Perlindungan Anak Indonesia”, Journal Fiat Justisia Ilmu Hukum, Volume 9, Nomor 1, Januari-Maret 2015.

Rahman Faiz dan Nur Rizka Faiza, "Perkawinan Siri Online Ditinjau Dari Prespektif Hukum Perkawinan Islam yang berlaku di Indonesia”, Journal Penelitian Hukum, Volume 1, Nomor 1, Maret 2014.

Rosana Ellya, "Kepatuhan Hukum sebagai Wujud Kesadaran Hukum Masyarakat”, Jurnal TAPIs, Volume 10, Nomor 1, Januari-Juni 2014.

Sibuea Harris Y.P, “Penegakan Hukum Pengaturan Minuman Beralkohol”, Jurnal Negara Hukum, Volume 7, Nomor 1, Juni 2016.

Zulfiani, "Kajian Hukum Terhadap Perkawinan Anak di Bawah Umur Menurut Undang-Undang Nomor 1 Tahun 1974”, Jurnal Hukum Samudra Keadilan, Volume 12, Nomor 2, Juli-September 2017.

\section{Internet:}

Badan Pusat Statistik (BPS), "Profil Anak Indonesia 2018", https://www.kemenpppa.go.id/lib/uploads/list/74d38-buku-pai-2018.pdf, diakses 02 September 2019. 


\section{Peraturan Perundang-Undangan}

Indonesia, Undang-Undang Nomor 1 Tahun 1974 tentang Perkawinan (Lembaran Negara Republik Indonesia Tahun 1974 Nomor 1)

Indonesia, Undang-Undang Nomor 23 Tahun 2002 tentang Perlindungan Anak (Lembaran Negara Republik Indonesia Tahun 2002 Nomor 109) 